ISSN: 2348-1900

Plant Science Today

http://www.plantsciencetoday.online

Mini Review

\title{
Vermicomposting of aquatic weeds: A quick review
}

\author{
Ishtiyaq Ahmed Najar \\ Department of Environmental Sciences, G.D. College, Ganderbal 191201, Kashmir (J\&K), India
}

Article history

Received: 18 May 2017

Accepted: 16 August 2017

Published: 04 September 2017

(C) Ishtiyaq (2017)

Editor

K K Sabu

Publisher

Horizon e-Publishing Group

Correspondence

Ishtiyaq Ahmed Najar

凶ishtiyaq.env@gmail.com

\begin{abstract}
Aquatic plants play an important role in ecosystem functioning and services but they can also be deleterious if present in excess. The different anthropogenic activities result in accumulation of nutrients in aquatic ecosystems leads to eutrophication with massive weed growth and associated diverse adverse effects. Effective control/management of weeds in different aquatic systems is not only difficult but of short duration. The commonly used methods to manage/control the aquatic weeds are biological, chemical and mechanical, in addition to habitat manipulation. However, these methods can be highly disruptive causing adverse environmental effects and are relatively inefficient. On the other hand different species of earthworms can feed on wide range of weeds and convert them into stable product called vermicompost, rich in plant nutrients. Among different aquatic weeds the most extensively vermicomposted weed is water hyacinth (Eichhornia crassipes (Mart.) Solms), using different earthworm species. Among different earthworm species used for vermicomposting of aquatic weeds, Eisenia fetida (Savigny) is the most commonly used species. Vermicomposting is an efficient ecobiotechnological process that converts the aquatic weeds into nutrient rich material that can acts as suitable plant growth media for sustainable agroecosystems. Further large scale utilization of aquatic weed based vermicompost in horticulture can solve their management and disposal issues along with restoration of organic matter and nutrient depletion at low input basis.
\end{abstract}

Keywords: Aquatic plants; Earthworms; Weeds; Vermicomposting

Ishtiyaq A N. Vermicomposting of aquatic weeds: A quick review. Plant Science Today 2017;4(3):133-136. doi: 10.14719/pst.2017.4.3.311

\section{Introduction}

Aquatic plant community comprise a diverse group of flora that occur seasonally or permanently in different wet environments. These plants are capable of colonizing wide range of aquatic environments (reservoirs, lakes, lagoons, wetlands, rivers and waterfalls) with varied limnological characteristics, presenting high plasticity and adaptation ability. They are vital in maintenance of food chains and various biogeochemical processes, but are deleterious when present in excess (1). However, anthropogenic activities results in accumulation of nutrients in aquatic ecosystems leads to eutrophication with massive plant growth which impairs recreational activities and ecosystem services $(2,3,4,5,6)$. 
Earthworms are among important invertebrate communities in soils in terms of their below ground biomass $(7,8,9)$ and play a major role in their functioning (10) along with essential ecosystem services (11). In different pedoecosystems they enhanced mineralisation and nutrient availability in soil $(12,6,13)$. They contribute to soil aeration, drainage and transformation of plant vitals (minerals and nutrients) to accessible forms, thus making the soil favorable for enhanced crop yield $(14,15,16)$.

Many studies have been documented on the use of vermicomposting in processing of different organic materials/wastes, but studies on its use in the processing of aquatic weeds have been few. Chauduri et al. (17) on vermicomposing of Trapa bispinosa with Perionyx excavatus reported increase in concentration of total nitrogen, available phosphorous, potassium and calcium. Sannigrahi et al. (18) vermicomposted fresh and dry form of water hyacinth (Eichhornia crassipes) using $P$. excavatus and recorded faster recycling in fresh form as compared to dry form. Gajalakshmi et al. (19) screened the potential of epigeic species (Eudrilus eugeniae and $P$. excavatus) and anecic species (Lampito mauritii and Drawida willsi) in vermicomposting of water hyacinth and reported E. eugeniae as relatively efficient in the recycling of water hyacinth and further concluded that precomposted weed forms were the mostly favored as feed by E. eugeniae (20). Deka et al. (21) vermicomposted water hyacinth by using Eisenia fetida and reported increase in macro and micro nutrients of the final product besides reduction in time taken for maturation of the compost. Kaniuczak et al. (22) reported increase in nitrogen, calcium, magnesium and sodium with good granular structure of vermicompost in pots with Lemna minor and E. fetida as compared to control without earthworms. Girijia et al. (23) on vermicomposting of Salvinia molesta and $E$. crassipes with $E$. fetida state that the vermicompost becomes ready for use within 40-45 days.

Gupta et al. (24) vermicomposed water hyacinth using E. fetida, reported its effective conversion when water hyacinth was mixed with $25 \%$ of cow dung (dry weight). Kostecka and Kaniuczak (25) vermicomposted Lemna minor (Duck weed) in small containers using E. fetida and recorded increase in earthworm number and biomass in containers with duckweed and manure dung than in containers with pure duckweed. According to Sannigrahi (26) noxious aquatic weeds- water lettuce (Pistia stratiotes), water hyacinth (E. crassipes) and cattail (Typha angustata) could be managed beneficially by converting them into good quality vermicompost within 2 to 3 months using $P$. excavates. Chauhan and Joshi (27) vermicomposted noxious weedwater hyacinth ( $E$. crassipes) by using $E$. fetida and results showed an increase in NPK and decrease in carbon and carbon:nitrogen ratio in the vermicompost as compared to control. Najar and Khan (28) recorded increased growth and reproduction in E. fetida while feeding on of Azolla sp. and confirmed that vermi based technology could be an effective to convert the menace of Azolla sp. into a value-added productvermicompost. Zirbes et al. (29) conducted experiment on the feasibility of water hyacinth $(E$. crassipes) mixed with pig manure in varied proportions using $P$. excavates and concluded that E. crassipes could be potential raw material in earthworm based composting and biofertilizing if blended with 75\% pig manure. Patil et al. (30) vermicomposted water hyacinth into vermicompost with poultry litter as supplement in a rotary drum reactor, using E. fetida and reported that conversion process completed in 45 days which is almost half the time taken by conventional methods (wedge method, bed and bin method) for management/conversion of water hyacinth. Najar and Khan (4) evaluated the potential of three earthworm species (Aporrectodea rosea rosea, A. caliginosa trapezoides and E. fetida) in management of fresh water weeds and recorded higher recycling potential in E. fetida among the three species based on the percent recycling of weed and physiochemical characteristics of final product. Gandhi and Sundari (31) vermicomposted Azolla sp. and Eichhornia sp. by using earthworms ( $E$. eugeniae) and studied the effect of vermicompost on growth and yield of egg plant.

Kannadasan et al. (32) confirmed sustainable worm based conversion of E. crassipes, using E. eugeniae and E. fetida and concluded that the compost was rich in prime plant nutrients. Najar and Khan (14) studied the potential of $E$. fetida to manage/recycle the different macrophytes in different combinations during two months experimentation and concluded that nature of weed affect $E$. fetida in terms of growth and reproduction, which in turn determines its recycling rate as ascertained by principal component analysis (PCA). Umavathi et al. (33) studied the vermicompost from the aquatic weed $E$. crassipes by employing the earthworm $E$. eugeniae and concluded that nutrients content of $E$. crassipes digested vermicompost were enhanced by the earthworm's digestive enzymes and gut microbes. Mishra et al. (34) confirmed the conversion of aquatic weeds- Azolla microphylla, Pistia stratiotes, Salvinia cucullata and Salvinia molesta with cow dung, using $P$. excavatus into vermicompost, thus considered vermitechnology as effective and ecofriendly technology for sustainable agriculture. Bernal et al. (35) worked on the conversion of water hyacinth using $E$. fetida and concluded that vermicomposting is suitable for managing water hyacinth as it produced a stable and mature product (vermicompost), rich in plant nutrients and thus can be used as organic fertilizer or soil improver. 


\section{Nutrient status of vermicompost}

Vermicompost is made of $\mathrm{C}, \mathrm{H}, \mathrm{O}$ and contains nutrients such as $\mathrm{NO}_{3}, \mathrm{PO}_{4}, \mathrm{Ca}, \mathrm{K}, \mathrm{Mg}, \mathrm{S}$ and other micro-nutrients which exhibit similar effects on plant growth and yield as inorganic fertilizers applied to soil (36). Similarly, vermicompost contains a high proportion of humic substances (humic acids, fulvic acids and humin) which provide numerous sites for chemical reaction known to enhance plant growth and disease suppression (37). Munroe (38) reported presence of chitinase enzyme in vermicast which breaks down the chitin in the exoskeleton of insects and thus repels different insect pests.

\section{Application of vermicompost}

There is accumulating scientific evidence that vermicompost can influence the growth and productivity of crops significantly. Different studies have confirmed the positive effects of vermicompost on a wide variety of crops including cereal and legumes (39), vegetables $(40,41)$, ornamental and flowering plants $(42,43)$ and field crops $(15,16,44,45,46,47,48)$.

\section{Conclusion}

Vermicomposting is non-thermophilic degradation of organic wastes by the action of earthworms. Vermicomposting of aquatic weeds not only helps in controlling the menace of aquatic weeds but at the same time it helps in control of eutrophication of aquatic systems as well, as they removes large quantities of nitrogen and phosphorous from water. Large scale utilization of aquatic weeds for vermicomposting helps in keeping water bodies free from excess weeds, which in turn improves their aesthetics. Thus vermicomposting is efficient method to convert aquatic weeds into vermicompost- a valuable eco-product for sustainable agriculture.

\section{Acknowledgements}

I sincerely thank Dr. Anisa B. Khan and Abdul Hai for their guidance.

\section{Competing interests}

The author declare that he has no competing interests.

\section{References}

1. Bianchini J I, Cunha-Santino M B, Milan J A M, Rodrigues C J, Dias J H P. Growth of Hydrilla verticillata (L.f.) Royle under controlled conditions. Hydrobiologia. 2010;644:301-312.

2. Ishtiyaq A N, Anisa B K, Abdul $\mathrm{H}$. Evaluation of seasonal variability in surface water quality of Shallow Valley Lake, Kashmir, India, using multivariate statistical techniques. Pollut. 2017; 3(3): 349-362. doi:10.7508/pj.2017.03. 001.
3. Najar I A, Khan A B. Earthworm communities of Kashmir Valley, J\&K, India. Trop Ecol. 2011a; 52(2):151-162.

4. Najar I A, Khan A B. Vermicomposting of fresh water weeds (macrophytes by Eisenia fetida (Savigny, 1826), Aporrectodea caliginosa trapezoides (Duges, 1828) and Aporrectodea rosea rosea (Savigny. Dyn Soil Dyn Plant. 2012a; 6(S1):73-77.

5. Najar I A, Khan A B. Assessment of water quality and identification of pollution sources of three lakes in Kashmir, India, using multivariate analysis. Environ Earth Sci. 2012b;66(8): 2367-2378. doi; 10.1007/s12665-011-1458-1.

6. Najar I A. Studies on earthworm communities of Kashmir Valley, their application in management of fresh water weeds (macrophytes) and use of vermicompost in horticulture. Ph.D thesis, Pondicherry University. 2012.

7. Smith R G, McSwiney C P, Grandy A S, Suwanwaree P, Snider R M, Robertson G P. Diversity and abundance of earthworms across an agricultural land-use intensity gradient. Soil and Tillage Res. 2008; 100: 83-88.

8. Najar I A, Khan A B. Assessment of pollution status of Khushalsar Lake, Kashmir, India using multivariate statistical techniques. Pollut Res. 2011b; 30(2):131-136.

9. Najar I A, Khan A B. Factors affecting distribution of earthworms in Kashmir Valley: a multivariate statistical approach. Proc Zool Soc. 2014; 67(2):126135. doi:10.1007/s12595-013-0081-4.

10. Ernst $\mathrm{G}$, Emmerling $\mathrm{C}$. Impact of five different tillage systems on soil organic carbon content and the density, biomass, and community composition of earthworms after a ten year period. Eur J Soil Biol. 2009; 45: 247-251.

11. Jouquet P, Plumere T, Thu T D, Rumpel C, Duc T T, Orange D. The rehabilitation of tropical soils using compost and vermicompost is affected by the presence of endogeic earthworms. Appl Soil Ecol. 2010; 46: 125-133.

12. Dominguez J, Aira M, Gomez-Brandon M. The role of earthworms on the decomposition of organic matter and nutrient cycling. Ecosistemas. 2009; 18(2): 20-31.

13. Najar I A, Khan A B. Management of fresh water weeds (macrophytes) by vermicomposting using Eisenia fetida. Environ Sci Pollut Res. 2013a; 20:64066417.doi: 10.1007/s11356-013-1687-9

14. Kizilkaya R, Karaca A, Turgay OC, Cetin S C. Earthworm interactions with soil enzymes. In Biology of earthworms, ed. A. Karaca. Berlin: Springer; 2011.

15. Najar IA, Khan A B. Effect of vermicompost on growth and productivity of tomato (Lycopersicon esculentum) under field conditions. Acta Biol Malaysiana. 2013b; 2(1):12-21.

16. Najar I A, Khan A B, Abdul H. Effect of macrophyte vermicompost on growth and productivity of brinjal (Solanum melongena) under field conditions. Int J Recycl Org Waste Agricult. 2015; 4(2):73-83. doi: 10.1007/s40093-015-0087-1.

17. Chauduri P, Pal T K, Bhattacharjee G, Dey S K. Nutrients changes during vermicomposting by Perionyx excavatus of the aquatic weed Trapa bispinosa. Philipp J Sci. 2001; 130(2):127-133. 
18. Sannigrahi A k, Chakrabortty S, Borah B C. Large scale Utilization of Water Hyacinth (Eichhornia crassipes) as raw material for vermicomposting and surface mulching in vegetable cultivation. Ecol Environ Conserv. 2002; 8(3): 269-271.

19. Gajalakshmi S A, Ramasamy E V, Abbasi S A. Potential of two epigeic and two anecic earthworm species in vermicomposting of water hyacinth. Biores Technol. 2001; 76:177-181.

20. Gajalakshmi S A, Ramasamy E V, Abbasi S A. Vermicomposting of different forms of water hyacinth by the earthworm Eudrilus eugeniae, Kinberg. Biores Technol. 2002; 82:165-169.

21. Deka P K, Paul S K, Bora H A. Vermitechnology for economic use and control of water hyacinth. Pollut Res. 2003; 22(3): 385-387.

22. Kaniuczak J, Kostecka J, Nowak M, Paczka G. Changes in chosen characteristics and macronutrient contents of the substrate with duckweed subjected to vermicomposting. Zeszyty Problemove Postepow Nauk Rolniczych. 2004; 49(8):95-102.

23. Girijia $\mathrm{T}$, Shama $\mathrm{P}$ K, Abraham $\mathrm{C} T$. Vermicomposting of aquatic weeds. Indian. $J$ Aquatic Weed Sci. 2005; 37(1/2):155-156.

24. Gupta R, Mutiyar P K, Rawat N K, Saini M S, Garg V K. Development of a water hyacinth based vermireactor using an epigeic earthworm Eisenia fetida. Biores Technol. 2007; 98(13):2605-2610.

25. Kostecka J, Kaniuczak J. Vermicomposting of duckweed (Lemna minor L.) biomass by Eisenia fetida. J Elementol. 2008; 13(4):571-579.

26. Sannigrahi A K. Management of some aquatic weeds through vermicomposting. Indian $J$ Environ Prot. 2009; 29(9): 809-811.

27. Chauhan A, Joshi P C. Composting of Some Dangerous and Toxic Weeds Using Eisenia fetida. J Am Sci. 2010; 6(3).

28. Najar I A, Khan A B. Vermicomposting of Azolla pinnata by using earthworm Eisenia fetida. The Bioscan. 2010; 5(2):239-241.

29. Zirbes L, Renard Q, Dufey J, Tu P K, Duyet H N, Lebailly P, Francis F, Haubruge E. Valorisation of a water hyacinth in vermicomposting using an epigeic earthworm Perionyx excavatus in Central Vietnam. Biotechnol Agron Soc Environ. 2011; 15(1): 85-93.

30. Patil J H, Sanil P H, Malini B M, Manoj V, Deepika D, Chaitra D. J Chem Pharm Res. 2012; 4(5):2585-2589.

31. Gandhi A, Sundari U S. Effect of vermicompost prepared from aquatic weeds on growth and yield of eggplant (Solanum melongena L.). J Biofertil Biopestici. 2012; 3(5):128. doi:10.4172/21556202.1000128.

32. Kannadasan N, Natarajan N, Anbusaravanan N, Sekar P, Krishnamoorthy R. Assessment of sustainable vermiconversion of water hyacinth by Eudrilus eugeniae and Eisenia fetida. J Appl Nat Sci. 2013; 5(2):451-454.

33. Umavathi S, Mathivanan R, Thangam Y, Revathi S. Effect of Eudrilus eugeniae in vermibioconversion of Eichhornia crassipes (Martius) Solms-Laubach. Environ Res Int. 2015; 1:10-17.

34. Mishra M, Mohapatra A, Satapathy K B. A comparative study of vermicompost prepared from phytoremediated and naturally grown aquatic weeds on growth and yield of green gram [Vigna radiata (L.) Wilczek]. Int J Curr Res Biosci Plant Biol. 2016; 3(7):104-109.

35. Bernal DA, Hernandez M A L, Osben H R B, Ramos S M C, Mora M. Vermicompost as an alternative of management for water hyacinth. Rev Int Contam Ambie. 2016; 32 (4): 425-433. doi: 10.20937/RICA.2016.32.04.06.

36. Singh R, Sarma R, Satyendra K, Gupta R, Patil R. Vermicompost substitution influences growth, physiological disorders, fruit yield and quality of strawberry (Fragaria xananassa (Duch.). Bioresour. Technol. 2008; 99: 8502-8511.

37. Theunissen J, Ndakidemi P A and Laubscher C P. Potential of vermicompost produced from plant waste on the growth and nutrient status in vegetable production. Int. J. Phy. Sci. 2010; 5(13):1964-1973.

38. Munroe G. Manual of On-farm Vermicomposting and Vermiculture. Publication of Organic Agriculture Centre of Canada, Nova Scotia. 2007; 39p.

39. Souzaa M E P, Carvalhoa A M X, Deliberali D C, Juckscha I, Brown G G, Mendonc E S, Cardosoa I M. Vermicomposting with rock powder increases plant growth. Appl. Soil. Ecol. 2013; 69:56-60.

40. Doan T T, Ngo P T, Rumpe C, Nguyen B N, Jouquet P. Interactions between compost, vermicompost and earthworms influence plant growth and yield: a one-year greenhouse experiment. Sci Hortic. 2013; 160:148-154.

41. Atiyeh R M, Arancon N Q, Edwards C A, Metzger J D. Influence of earthworm-processed pig manure on the growth and yield of greenhouse tomatoes. Bioresour. Technol. 2000a; 75:175-180.

42. Edwards CA, Burrows I. The potential of earthworm compost as plant growth media. In: Edwards CA, Neuhauser (eds) Earthworms in environmental and waste management. SPB Academic Publishers. The Netherlands. 1988; 211-220.

43. Atiyeh RM, Dominguez J, Subler S, Edwards CA. Changes in biochemical properties of cow manure during processing by earthworms (Eisenia andrei, Bouche) and the effects on seedling growth. Pedobiologia. 2000b; 44:709-724.

44. Wu Y, Zhang N, Wang J, Sun Z. An integrated crop vermiculture system for treating organic waste on fields. Eur. J. Soil Biol. 2012; 51:8-14.

45. Rajeev S, Dwivedi H S, Dwivedi P. Utilization of three obnoxious weeds (Parthenium hysterophorus, Lantana camara and Eichhornia crassipes) through vermicomposting and their response on vegetative growth of Soybean crop. Int. J. Adv. Res. Biol. Sci. 2016; 3(9):13-20.

46. Khan V M, Ahamad A, Yadav BL, Irfan M. Effect of Vermicompost and Biofertilizers on Yield Attributes and Nutrient Content and it's their Uptake of Cowpea [Vigna unguiculata (L.)Walp.]. Int. J.Curr.Microbiol. App. Sci. 2017; 6(6): 1045-1050.

47. Sahoo H R, Gupta N. Of Vermicompost In Enhancing Growth And Development Of Piper Longum- A Ret Medicinal Plant. Sci. Agri. 2017; 17 (3): 77-81.

48. Roychowdhury D, Mondal S, Banerjee S K. The Effect of Biofertilizers and the Effect of Vermicompost on the Cultivation and Productivity of Maize - A Review. Adv. Crop. Sci. Tech. 2017;5:261. doi: 10.4172/2329-8863.1000261. 